\title{
INFLUENCE OF THE SELECTED PARAMETERS ON THE EFFECTIVENESS OF IGCC SYSTEM INTEGRATED WITH CCS INSTALLATION
}

\author{
Anna Skorek-Osikowska*, Łukasz Bartela, Janusz Kotowicz \\ Silesian University of Technology, Institute of Power Engineering and Turbomachinery, \\ ul. Konarskiego 18, 44-100 Gliwice, Poland
}

\begin{abstract}
The paper presents the basic input data and modelling results of IGCC system with membrane $\mathrm{CO}_{2}$ capture installation and without capture. The models were built using commercial software (Aspen and GateCycle) and with the use of authors' own computational codes. The main parameters of the systems were calculated, such as gross and net power, auxiliary power of individual installations and efficiencies. The models were used for the economic and ecological analysis of the systems. The Break Even Point method of analysis was used. The calculations took into account the EU emissions trading scheme. Sensitivity analysis on the influence of selected quantities on break-even price of electricity was performed.
\end{abstract}

Keywords: IGCC, modelling, $\mathrm{CO}_{2}$ capture, membranes, economic analysis

\section{INTRODUCTION}

Despite numerous efforts aiming to increase energy production from renewable sources, coal for a long will remain the main fuel in electricity generation systems. Currently, nearly $40 \%$ of global electricity is produced from coal. The main reason for that is the price and availability of coal resources. On the other hand, mandatory for members of the European Union the Emissions Trading Scheme (ETS) and other international commitments (e.g., energy-climate package), should lead to significant reductions of greenhouse gas emissions to the atmosphere. This challenge is difficult to achieve, especially in energy systems based on combustion of coal. Therefore, the technologies are developed, which in the future should allow for nearly emission-free electricity production from fossil fuels, including precombustion, post-combustion and oxy-combustion, described and evaluated e.g. in (Bartela et al., 2014a; Bartela et al., 2014b; Desideri and Paolucci 1999; Feron, 2009; Skorek-Osikowska et al., 2013, Toftegaard et al., 2010; Zheng, 2011). The IGCC (Integrated Gasification Combined Cycle) is a precombustion system. In this kind of system fuel is gasified in a gas generator, forming a combustible synthesis gas, whose composition depends primarily on the type of generator and the parameters of the gasification process. Gas is then cleaned and combusted in a gas turbine, which generates most of electric power produced in the system. The rest of power is produced from the expansion work of steam in a steam turbine installation.

The main advantage of IGCC systems is higher, compared to the conventional coal-fuelled power plants, efficiency of electricity generation (Badyda et al., 2010; Cormos, 2012; Maustrad, 2005). However, if the systems should be treated as zero-emission, they must be integrated with carbon

*Corresponding author, e-mail: anna.skorek@polsl.pl 
capture and storage (CCS) installation. Due to the fact that the $\mathrm{CO}_{2}$ capture is realised from the process gas with a relatively high content of carbon dioxide before the combustion process, and not, as in conventional systems, from flue gases with low $\mathrm{CO}_{2}$ content, less energy-intensive separation methods, including physical absorption process or membrane separation are used here. Thus, even though current IGCC systems are not competitive with conventional electricity generation from coal, they are considered prospective in the face of the necessity to significantly reduce carbon dioxide emissions and, therefore, when the emissions trading scheme will be valid in the final form. It results mainly from the better ecological characteristics of these systems (due to the higher efficiency) and less energyintensive methods of separating carbon dioxide from the synthesis gas (due to the greater proportion of $\mathrm{CO}_{2}$ in the gas and implementation of the capture process before the combustion).

The main objective of the work presented in this paper is the economic and ecological evaluation of an IGCC system integrated with a membrane installation for carbon dioxide capture and comparison of the systems with and without the $\mathrm{CO}_{2}$ capture installation in the context of the EU emissions trading scheme.

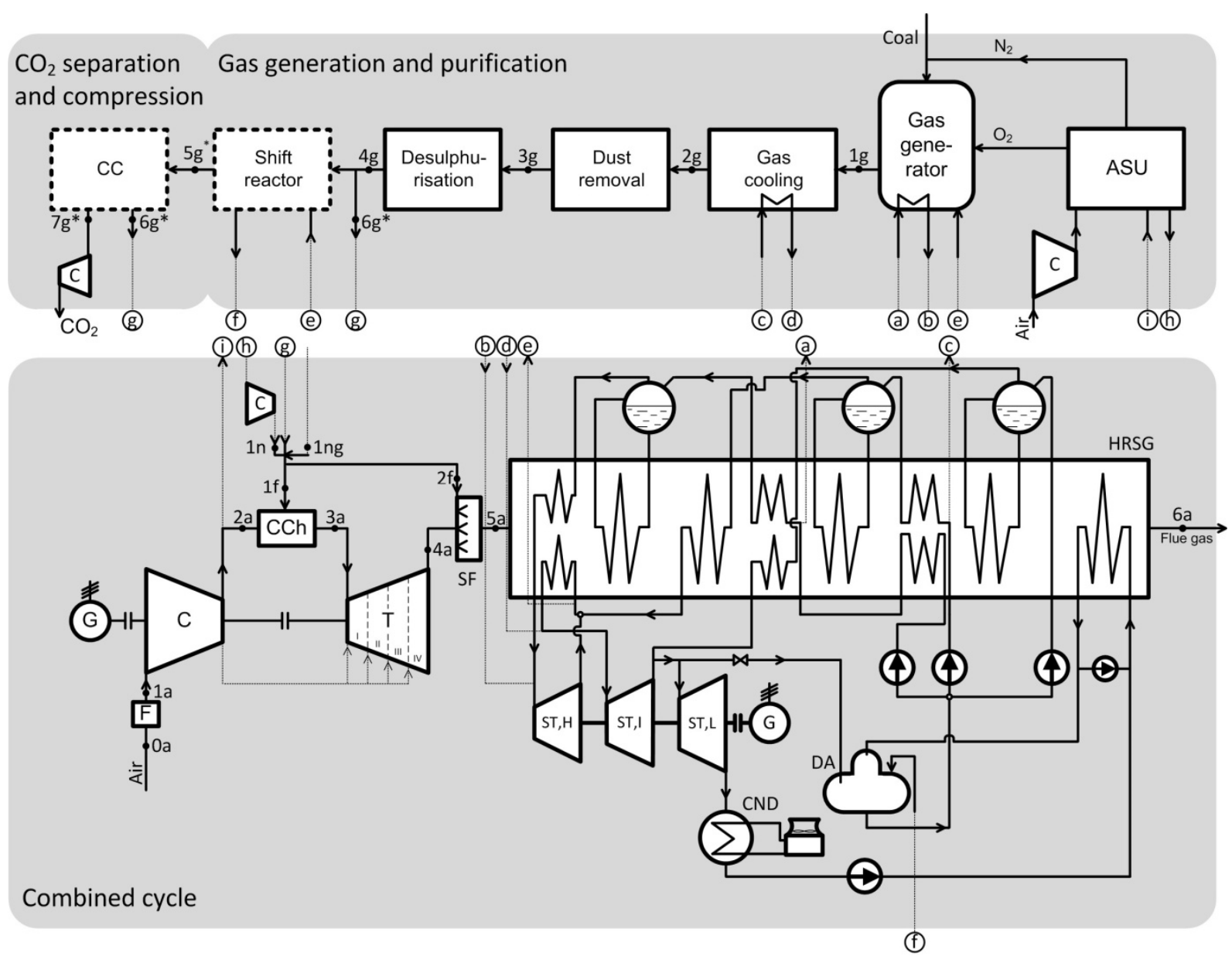

Fig. 1. Scheme of IGCC system without and with $\mathrm{CO}_{2}$ capture; with a dashed line installations required in the case of $\mathrm{CO}_{2}$ capture are marked;

ASU - Air Separation Unit, C - Compressor, G - Generator, ST - Steam turbine, CND - condenser,

$\mathrm{DA}$ - deaerator, $\mathrm{CCh}$ - combustion chamber, HRSG - Heat recovery steam generator, F - filter

\section{DESCRIPTION OF IGCC SYSTEM}

In order to achieve the main objectives of the work, a model of an integrated gasification combined cycle was built. This system consists of an air separation unit (ASU) producing technical oxygen, gas 
generator, a path of gas cleaning and cooling before supplying it to the gas turbine system, a gas turbine installation and a steam-water cycle with a steam turbine.

Carbon dioxide capture requires additional installations within the plant, including mainly the shift reactor (conversion of $\mathrm{CO}$ to $\mathrm{CO}_{2}$ with the use of steam), the installation of $\mathrm{CO}_{2}$ separation (e.g., absorption or membrane) and the compression installation of captured carbon dioxide before its transport to the storage place. It is also necessary to adapt the gas turbine to the combustion of gas with high hydrogen content. Diagram of IGCC plant with and without carbon capture installation is shown in Fig. 1.

For the calculation a pressurised, oxygen-fed, entrained flow gasifier (based on Shell technology, (Cormos, 2012; Maustrad, 2005; Smitha et al., 2008; Sun et al., 2011; Zheng and Furinsky, 2005)), powered with coal with the composition shown in Table 1 was chosen.

Coal is transported to the gas generator using nitrogen from ASU. Gasifying medium is oxygen with a purity of $95 \%$, supplied from the cryogenic oxygen plant, and water vapour. The amount of oxygen is determined on the basis of stoichiometric calculations of the process for the excess air ratio $\lambda=0.42$. The oxidant is fed to the generator at a pressure equal to the gasification pressure $(4 \mathrm{MPa})$.

Table 1. Composition and main parameters of coal

\begin{tabular}{|l|c|}
\hline \multicolumn{1}{|c|}{ Parameter } & Value \\
\hline \multicolumn{2}{|c|}{ Ultimate analysis [\%] } \\
\hline carbon & 72.04 \\
\hline hydrogen & 4.08 \\
\hline nitrogen & 1.67 \\
\hline oxygen & 7.36 \\
\hline sulphur & 0.65 \\
\hline chlorine & 0.01 \\
\hline \multicolumn{2}{|c|}{ Proximate analysis [\%] } \\
\hline moisture & 8.10 \\
\hline ash & 14.19 \\
\hline volatile matter & 28.51 \\
\hline lower heating value, MJ/kg & 27.80 \\
\hline
\end{tabular}

Gas from generator is cooled and cleaned (primarily particulates and sulphur compounds are removed) and then goes to the gas turbine combustion chamber. Enthalpy of the flue gas from a gas turbine is used for production of steam in the three-pressure heat recovery steam generator (HRSG). The model assumes that the gas turbine is not integrated with the compressor in the air separation unit. It was also assumed that, regardless the variant (with or without $\mathrm{CO}_{2}$ capture) the gas turbine does not change, while the other components of the systems are the results of modelling of this machine. This means that the stream of coal at the inlet to the gas generation system is calculated in such a way to produce the stream of gas that is necessary to obtain a determined maximum power of the gas turbine. This causes differences in the auxiliary power of the individual installations within both systems. The most important parameters of the systems without (IGCC) and with $\mathrm{CO}_{2}$ capture (IGCC+CCS) are summarised in Table 2.

In the case of carbon dioxide capture it is necessary to implement an additional reactor of the conversion of carbon monoxide to carbon dioxide (Shift) and the installation of $\mathrm{CO}_{2}$ separation from a process gas. To the Shift reactor steam at parameters 54.67 bar and $369^{\circ} \mathrm{C}$ is supplied from the steam 
cycle. As a result, carbon monoxide is converted to carbon dioxide and the process gas is enriched in hydrogen, according to the reaction:

$$
\mathrm{CO}+\mathrm{H}_{2} \mathrm{O} \rightarrow \mathrm{CO}_{2}+\mathrm{H}_{2}
$$

Table 2. Main input data for a model of an IGCC system

\begin{tabular}{|c|c|c|c|}
\hline Quantity & Unit & IGCC & $\mathrm{IGCC}+\mathrm{CCS}$ \\
\hline \multicolumn{4}{|c|}{ ASU } \\
\hline Air stream & $\mathrm{kg} / \mathrm{s}$ & 125.30 & 166.16 \\
\hline Air composition: oxygen/nitrogen share & - & $0.21 / 0.79$ & $0.21 / 0.79$ \\
\hline Technical oxygen purity & - & 0.95 & 0.95 \\
\hline Technical oxygen stream & $\mathrm{kg} / \mathrm{s}$ & 30.54 & 38.48 \\
\hline Energy intensity of ASU & $\mathrm{kWh} / \mathrm{kgO}_{2}$ & 0.22 & 0.22 \\
\hline Auxiliary power of ASU & MW & 23.12 & 29.13 \\
\hline Power of oxidant compressor & MW & 11.79 & 14.85 \\
\hline \multicolumn{4}{|c|}{ Gasifier } \\
\hline Gasification pressure & bar & 40.0 & 40.0 \\
\hline Coal stream & $\mathrm{kg} / \mathrm{s}$ & 34.69 & 43.71 \\
\hline Oxygen/coal stream ratio & $\mathrm{kg} / \mathrm{kg}$ & 0.89 & 0.89 \\
\hline Steam/coal stream ratio & $\mathrm{kg} / \mathrm{kg}$ & 0.13 & 0.13 \\
\hline Nitrogen used for coal transport/coal stream ratio & $\mathrm{kg} / \mathrm{kg}$ & 0.09 & 0.09 \\
\hline \multicolumn{4}{|c|}{ Gas purification system } \\
\hline Efficiency of dust removal & $\%$ & 99.0 & 99.0 \\
\hline Stream of water vapour directed to Shift reactor & $\mathrm{kg} / \mathrm{s}$ & - & 57.62 \\
\hline Temperature of steam directed to Shift reactor & ${ }^{\circ} \mathrm{C}$ & - & 369 \\
\hline Pressure of steam directed to Shift reactor & bar & - & 54.67 \\
\hline \multicolumn{4}{|c|}{ Carbon dioxide capture and compression } \\
\hline $\begin{array}{l}\text { Permeation coefficients of the membranes } \\
\mathrm{CO}_{2} \\
\mathrm{H}_{2} \mathrm{O} \\
\mathrm{N}_{2} \\
\mathrm{H}_{2} \\
\mathrm{CO}\end{array}$ & $\begin{array}{l}\mathrm{m}_{\mathrm{u}}^{3} /\left(\mathrm{m}^{2} \mathrm{hbar}\right) \\
\mathrm{m}_{\mathrm{u}}^{3} /\left(\mathrm{m}^{2} \mathrm{hbar}\right) \\
\mathrm{m}_{\mathrm{u}}^{3} /\left(\mathrm{m}^{2} \mathrm{hbar}\right) \\
\mathrm{m}_{\mathrm{u}}^{3} /\left(\mathrm{m}^{2} \mathrm{hbar}\right) \\
\mathrm{m}_{\mathrm{u}}^{3} /\left(\mathrm{m}^{2} \mathrm{hbar}\right)\end{array}$ & $\begin{array}{l}- \\
- \\
- \\
-\end{array}$ & $\begin{array}{c}0.05 \\
0.00025 \\
0.00017 \\
0.0005 \\
0.0013\end{array}$ \\
\hline Feed pressure & bar & - & 34.0 \\
\hline Feed temperature & ${ }^{\circ} \mathrm{C}$ & & 40 \\
\hline Permeate pressure & bar & & 1.0 \\
\hline Carbon dioxide recovery rate & $\%$ & & 91.34 \\
\hline Final pressure in the $\mathrm{CO}_{2}$ compression installation & bar & & 150 \\
\hline Energy intensity of the compression installation & $\mathrm{kWh} / \mathrm{kgCO}_{2}$ & & 0.108 \\
\hline Auxiliary power of the capture process & MW & & 0.00 \\
\hline Auxiliary power of the compression installation & MW & & 35.22 \\
\hline
\end{tabular}

It was assumed in the analysis that one gas turbine operates in the system. However, no specific model was chosen but only a set of turbine parameters with specified power was adopted, provided by the manufacturers to work also in IGCC systems. Gas turbine installation powered by a fuel other than 
designed, needs to be adapted to the new working conditions. This is particularly problematic in the case of gas turbines fuelled with high-hydrogen content fuel, and therefore for the system with carbon dioxide capture. Detailed analyses of the methods to counteract the negative effects of burning such fuel are presented elsewhere (Bartela and Kotowicz, 2011). The analysis assumed that the process gas before being burned in a gas turbine combustion chamber is diluted with nitrogen derived from the air separation unit. This requires the use of a compressor that compresses nitrogen to a pressure required in the gas turbine combustion chamber. It was assumed that in the process without $\mathrm{CO}_{2}$ capture, the gas is diluted to such a degree to obtain the same flame temperature as that when the designed fuel (natural gas) is supplied to the turbine. In the system with $\mathrm{CO}_{2}$ capture installation the amount of nitrogen supplied to the combustion chamber together with the process gas may result from a maximum specified by the turbine manufacturer for the proportion of hydrogen (General Electric, 2009). In the analysis the fraction of hydrogen in the gas mixture at $60 \%$ was assumed.

In the calculations it was assumed that the carbon dioxide capture in IGCC system is realised with membranes for gas separation. Although this is a technology that cannot be regarded as commercially fully mature, according to the literature, it is possible to reduce energy consumption in the $\mathrm{CO}_{2}$ capture process in comparison to other methods of separation. For the analysis it was assumed that the capture system is composed of a membrane installation consisting of polymer membranes with polivinyloaminy FSC (fixed site carrier polyvinyleamine) selective for carbon dioxide (carbon dioxide passes through the membrane). These membranes were selected for the analysis based on the authors' previous studies (Kotowicz et al., 2010a; Kotowicz et al., 2010b; Kotowicz and Bartela, 2012; Kotowicz and Janusz-Szymańska, 2010; Skorek-Osikowska et al., 2012a; Skorek-Osikowska et al., $2012 \mathrm{~b}$ ). The main target of the selection was the possibility of obtaining assumed $\mathrm{CO}_{2}$ purity and recovery rate (at least $90 \%$ ). They are characterised by the $\mathrm{H}_{2}$ permeability coefficient equal to $0.0005 \mathrm{~m}_{\mathrm{u}}^{3} /\left(\mathrm{m}^{2} \cdot \mathrm{h} \cdot\right.$ bar $)$, the $\mathrm{CO}_{2}$ permeability equal to $0.05 \mathrm{~m}_{\mathrm{u}}^{3} /\left(\mathrm{m}^{2} \cdot \mathrm{h} \cdot \mathrm{bar}\right)$, and selectivity to carbon dioxide $\alpha^{*}=100$ (Grainger and Hagg, 2008). A scheme of the membrane module is shown in Fig. 2.

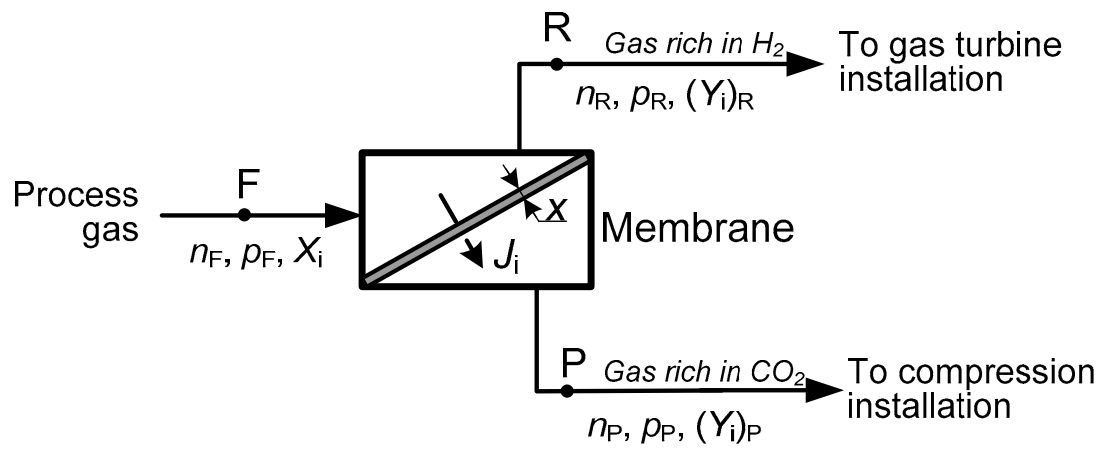

Fig. 2. Scheme of a membrane selective for carbon dioxide

Due to the fact that according to the relation used for determining the stream permeating through the membrane $d J_{\mathrm{i}}$ (denotations in accordance with Fig. 2):

$$
d J_{\mathrm{i}}=\frac{P_{\mathrm{i}}}{\delta}\left(p_{\mathrm{F}} X_{\mathrm{i}}-p_{\mathrm{P}} Y_{\mathrm{i}}\right) d A_{\mathrm{m}}
$$

the main parameter deciding about the quality of the separation process is, in addition to the parameters characterising the properties of the membrane, the partial pressure difference on both sides of the membrane, membrane systems are particularly predisposed for $\mathrm{CO}_{2}$ capture in IGCC systems. The gas resulting from coal gasification in pressurised gasifiers has usually such a high pressure that the use of additional machines (compressors or vacuum pumps) is not needed. This allows for significant reduction of the energy demand of the carbon dioxide capture process. 
The last element indispensible in the case of carbon dioxide capture is an installation of its compression before its transport to a storage place. In the literature there are no precise requirements for the parameters of a stream of captured carbon dioxide and the available data are based mainly on the American experience in the mining industry (Zheng, 2011). Therefore, the calculation assumes that carbon dioxide will be transported as a supercritical fluid and the final pressure in the compression installation will amount to 150 bar. The purity of the captured $\mathrm{CO}_{2}$-rich stream results from the properties of the separation plant but it was assumed that it cannot be less than 0.9 . The installation consists of a four-section compressor with interstage cooling to $30^{\circ} \mathrm{C}$. The heat from cooling sections of the compressor is not used in the cycle.

\section{RESULTS OF MODELING OF THE SYSTEMS}

For building models of the integrated gasification combined cycle with $\mathrm{CO}_{2}$ capture installation, commercial programs were used, including Aspen Plus (model of gas generation and purification, oxygen production and compression of carbon dioxide before transport), GateCycle ${ }^{\mathrm{TM}}$ (gas turbine installation, heat recovery steam generator and steam-water cycle) and Aspen Custom Modeler (membrane for $\mathrm{CO}_{2}$ separation from the process gas). During the process of building the models the authors took advantage of the experience gained in previous works related to the modelling of energy systems, e.g. (Desideri and Paolucci, 1999; Kotowicz et al., 2010; Kotowicz et al., 2011). Models of individual installations and the model of the whole installation were validated on the basis of the literature data e.g. (Cormos, 2012; Desideri and Paolucci, 1999; Feron, 2009). The models can be used to define the most important thermodynamic parameters of streams at different points, and the power of machines and equipment in the plants, used for ecological and economic analyses. Selected data concerning stream parameters in the system are shown in Tables 3 and 4. They concern the systems without and with $\mathrm{CO}_{2}$ capture.

For a selected gas turbine gross and net power of the whole system as well as auxiliary power of the system with and without $\mathrm{CO}_{2}$ capture were calculated. Power in IGCC plants is generated both in the gas turbine and steam turbine installation. The auxiliary power is affected mainly by the power of the air separation unit, system for coal preparation and transport, generation and purification of the process gas, steam-turbine installation, gas turbine installation and, in the case of the systems integrated with $\mathrm{CO}_{2}$ capture, the power needed to capture and compress carbon dioxide prior to transport.

Table 3. Main parameters of the gas and gas composition in the selected points of IGCC system without $\mathrm{CO}_{2}$ capture; denotations according to the Fig. 1

\begin{tabular}{|l|c|c|c|c|}
\hline \multicolumn{1}{|c|}{ Parameter } & $\begin{array}{c}\text { Raw gas } \\
(1 \mathrm{~g})\end{array}$ & $\begin{array}{c}\text { Purified gas } \\
(4 \mathrm{~g})\end{array}$ & $\begin{array}{c}\text { Gas to gas turbine } \\
(1 \mathrm{f})\end{array}$ & $\begin{array}{c}\text { Flue gas } \\
(5 \mathrm{a})\end{array}$ \\
\hline Temperature, ${ }^{\circ} \mathrm{C}$ & 1600 & 40 & 15 & 85 \\
\hline Pressure, bar & 38.5 & 36.61 & 27.8 & 1.02 \\
\hline Flow rate, $\mathrm{kg} / \mathrm{s}$ & 72.87 & 67.17 & 92.21 & 717.11 \\
\hline $\mathrm{H}_{2}, \%$ vol & 26.23 & 28.40 & 22.14 & 0.00 \\
$\mathrm{CO}_{2}, \%$ vol & 4.18 & 4.55 & 3.55 & 8.53 \\
$\mathrm{CO} \%$ vol & 56.46 & 61.11 & 47.64 & 0.00 \\
$\mathrm{~N}_{2}, \%$ vol & 4.61 & 5.07 & 25.99 & 74.80 \\
$\mathrm{H}_{2} \mathrm{O}, \%$ vol & 4.68 & 0.01 & 0.01 & 3.78 \\
other, \% vol & 3.84 & 0.86 & 0.67 & 12.89 \\
\hline $\mathrm{LHV}, \mathrm{MJ} / \mathrm{kg}$ & 11453 & 11840 & 8238 & - \\
\hline
\end{tabular}


Table 4. Main parameters of the gas and gas composition in the selected points of IGCC system with $\mathrm{CO}_{2}$ capture; denotations according to the Fig. 1

\begin{tabular}{|l|r|r|r|r|r|r|r|}
\hline \multicolumn{1}{|c|}{ Parameter } & $\begin{array}{c}\text { Raw } \\
\text { gas }(1 \mathrm{~g})\end{array}$ & $\begin{array}{c}\text { Purified } \\
\text { gas }(4 \mathrm{~g})\end{array}$ & $\begin{array}{c}\text { Gas before } \\
\text { membrane } \\
\left(5 \mathrm{~g}^{*}\right)\end{array}$ & $\begin{array}{c}\text { Retentate } \\
\left(6 \mathrm{~g}^{*}\right)\end{array}$ & $\begin{array}{c}\text { Perme- } \\
\text { ate } \\
\left(7 \mathrm{~g}^{*}\right)\end{array}$ & $\begin{array}{c}\text { Gas to gas } \\
\text { turbine }(1 \mathrm{f})\end{array}$ & $\begin{array}{c}\text { Flue gas } \\
(5 \mathrm{a})\end{array}$ \\
\hline Temperature, ${ }^{\circ} \mathrm{C}$ & 1600 & 40 & 40 & 40 & 40 & 15 & 85 \\
\hline Pressure, bar & 38.5 & 36.61 & 34.00 & 34.00 & 1.00 & 26.92 & 1.05 \\
\hline Flow rate, $\mathrm{kg} / \mathrm{s}$ & 91.80 & 84.62 & 114.01 & 23.69 & 90.32 & 64.98 & 692.56 \\
\hline $\mathrm{H}_{2}, \%$ vol & 26.23 & 28.40 & 54.50 & 85.05 & 4.43 & 60.00 & 0.00 \\
$\mathrm{CO}_{2}, \%$ vol & 4.18 & 4.55 & 39.51 & 5.51 & 95.23 & 3.89 & 1.09 \\
$\mathrm{CO}_{2} \%$ vol & 56.46 & 61.11 & 3.27 & 5.23 & 0.00 & 3.69 & 0.00 \\
$\mathrm{~N}_{2} \% \%$ vol & 4.61 & 5.07 & 2.44 & 3.76 & 0.28 & 32.10 & 74.72 \\
$\mathrm{H}_{2} \mathrm{O}, \%$ vol & 4.68 & 0.01 & 0.28 & 0.45 & 0.01 & 0.32 & 12.64 \\
other, \% vol & 3.84 & 0.86 & 0.00 & 0.00 & 0.00 & 0.00 & 11.54 \\
\hline $\mathrm{LHV}, \mathrm{kJ} / \mathrm{kg}$ & 11.45 & 11.84 & 7.01 & 32.79 & - & 11.92 & - \\
\hline
\end{tabular}

These quantities were determined based on the results of modelling of the individual installations. The main data concerning thermodynamic parameters and environmental indicators of particular installations are presented in Table 5.

Table 5. Selected characteristic environmental and thermodynamic parameters of the analysed technologies

\begin{tabular}{|l|c|r|r|}
\hline \multicolumn{1}{|c|}{ Quantity } & & \multicolumn{1}{c|}{ IGCC } & IGCC+CCS \\
\hline Gross power & $\mathrm{MW}$ & 508.03 & 484.67 \\
\hline Total auxiliary power of the system & $\mathrm{MW}$ & 66.71 & 120.80 \\
\hline Net power & $\mathrm{MW}$ & 441.31 & 363.87 \\
\hline Power of the gas turbine & $\mathrm{MW}$ & 289.05 & 305.87 \\
\hline Power of the steam turbine & $\mathrm{MW}$ & 218.98 & 178.80 \\
\hline Process gas chemical energy flux & $\mathrm{MJ} / \mathrm{s}$ & 834.55 & 1051.36 \\
\hline Coal energy flux & $\mathrm{MJ} / \mathrm{s}$ & 946.43 & 1192.33 \\
\hline $\mathrm{CO}_{2}$ emission & $\mathrm{kg} / \mathrm{s}$ & 91.19 & 16.68 \\
\hline $\mathrm{CO}_{2}$ emission incriminating a unit of gas/coal chemical energy & $\mathrm{kgCO} / \mathrm{GJ}$ & 96.35 & 13.99 \\
\hline $\mathrm{CO}_{2}$ emission incriminating unit of electricity produced & $\mathrm{kgCO} / \mathrm{MWh}$ & 646.19 & 123.89 \\
\hline $\mathrm{Gross}^{\prime}$ efficiency & $\%$ & 53.68 & 40.65 \\
\hline $\mathrm{Net}^{\prime}$ efficiency & $\%$ & 46.63 & 30.52 \\
\hline
\end{tabular}

\section{MAIN ASSUMPTIONS FOR ECONOMIC AND ECOLOGICAL ANALYSIS}

Economic analysis was carried out for the IGCC systems, using the authors' own computational algorithm built in the Excel environment. For the model of the system with and without the capture installation, key economic indicators were adopted, such as unit investment costs, operating costs or cost of financial services. To assess the economic efficiency of the analysed solutions the $N P V$ (Net Present Value) indicator was mainly used. The net present value results from adding (cumulating) the discounted cash flow $\left(C F_{t}\right)$ in all the years of operation, at a known level of the discount rate $r$. The condition for the profitability of the project is a positive $N P V$ value. A situation where $N P V=0$ means, that the project did not bring a profit, but the invested capital has been returned. The $N P V$ is calculated from the formula: 


$$
N P V=\sum_{t=0}^{t=\mathrm{N}} \frac{C F_{t}}{(1+r)^{t}}
$$

From the condition of setting to zero the net present value $(N P V=0)$ the break-even price of electricity was determined $c_{\mathrm{el}}^{\mathrm{b}-\mathrm{e}}$, which is in fact the minimum sale price of the produced electricity, that ensures profitability of the investment. Taking into account all the components of cash flow, the formula for determining the break-even price has the following form:

$$
C_{\mathrm{el}}^{\mathrm{b}-\mathrm{e}}=\frac{\sum_{t=0}^{t=\mathrm{N}} \frac{\left\lfloor J+\left(K_{\mathrm{PR}}+P_{\mathrm{d}}+K_{\mathrm{obr}}\right)-A-F-L\right\rfloor}{(1+r)^{t}}}{\sum_{t=0}^{t=\mathrm{N}} \frac{\left(E_{\mathrm{el}}-E_{\mathrm{el} \_\mathrm{pw}}\right)_{t}}{(1+r)^{t}}}
$$

Values of the individual components of the cash flows were determined according to the methodology presented e.g. in (Kotowicz, 2009; Skorek and Kalina, 2005) and another paper of the authors (Kotowicz et al., 2011, Skorek-Osikowska et al., 2014). The calculations took into account the size of the investment in fixed assets, cost of fuel, non-fuel costs (e.g. costs of operation, maintenance and repairs, cost of salaries) and the costs of carbon dioxide emission. Data for the economic calculations were taken from the available literature, e.g. (Cormos, 2012; Descamps et al., 2008; Grainger and Hagg, 2008; Huang et al., 2008; Kotowicz and Janusz-Szymańska, 2010; Malko, 2011; Melchior and Madlener, 2012; Ściążko et al., 2006; Zhao et al., 2009), especially in the form of indicators of the unit or absolute values. The most important ones are presented in Table 6 .

Determination of the unit investment costs for the purchase of machinery and equipment is often based on published literature data from existing systems (most reliable) or on estimating of the cost based on approximation curves. These indicators are often determined with the exponential equation (Skorek and Kalina, 2005):

$$
C_{\mathrm{U}}=C_{\mathrm{R}}\left(\frac{X_{\mathrm{U}}}{X_{\mathrm{R}}}\right)
$$

The value of the $\alpha$ exponent is for the energy systems typically assumed in the range between 0.6 and 0.7 .

The investment costs were estimated for such installations as: gas generator island, installation of the cryogenic air separation unit, gas purification system, gas-turbine installation and steam-water cycle. Additionally, in the case of a system with $\mathrm{CO}_{2}$ capture, unit investments for Shift reactor, membrane $\mathrm{CO}_{2}$ capture and compression installation as well as for transport and injection of captured carbon dioxide were determined. In this paper, the investments in individual plants were determined based on the specific investment costs indicators $j$ or with approximation formulas. Unit cost indicators are expressed in monetary units (e.g., PLN, $€$ ) related to the typical parameters of the systems, machinery or equipment, e.g. nominal power. As an example, specific investments in a gas turbine, expressed in $€ / \mathrm{kW}_{\mathrm{e}, \mathrm{b}}$, was determined from the relation (Skorek and Kalina, 2005):

$$
j_{\mathrm{TG}}=5082.4\left(N_{\text {elTG,nom }}\right)^{-0.271}
$$

the total investment cost for the compressor in the carbon dioxide compression installation before transport from the formula (Kotowicz and Janusz-Szymańska, 2010):

$$
j_{\mathrm{C}, \mathrm{CCS}}=1.051 \frac{\left(39.5 \dot{m}_{\mathrm{CO} 2}\right)}{0.9-\eta_{\mathrm{C}}} \eta_{\mathrm{C}} \ln \beta
$$


The investment cost on the membrane module was estimated according to (Kotowicz and JanuszSzymańska, 2010), assuming the price of one square meter of membrane equal to $16 €$.

Determined from the relation (5) to (7) and the available literature data (mainly (Cormos, 2012; Descamps et al., 2008; Grainger and Hagg, 2008; Huang et al., 2008; Kotowicz and Janusz-Szymańska, 2010; Melchior and Madlener, 2012; Ściążko, 2008; Ściążko et al., 2006; Zhao et al., 2009)) specific investment costs for particular installations in IGCC system with and without carbon dioxide capture are shown in Table 7.

Main data assumed for the economic analysis are gathered in Table 6. The analysis included the functioning of the emissions trading scheme and therefore charge for $\mathrm{CO}_{2}$ emissions. The allocation of free emission allowances was not taken into account.

Table 6. Specific investment cost on particular installations, expressed in $€ / \mathrm{kW}_{\mathrm{e}, \mathrm{b}}$

\begin{tabular}{|l|r|r|}
\hline \multicolumn{1}{|c|}{ Installation } & IGCC & IGCC+CCS \\
\hline Coal preparation installation & 71 & 79 \\
\hline Gas generator & 283 & 317 \\
\hline ASU & 172 & 190 \\
\hline Gas purification installation & 99 & 111 \\
\hline Gas turbine installation & 174 & 174 \\
\hline Power generation system & 460 & 463 \\
\hline Other (site, utilities, permissions, prime costs, etc.) & 423 & 523 \\
\hline Shift reactor & - & 40 \\
\hline Membrane $\mathrm{CO}_{2}$ capture installation & - & 75 \\
\hline $\mathrm{CO}_{2}$ compression installation & - & 51 \\
\hline Total & 1682 & 2024 \\
\hline
\end{tabular}

\section{RESULTS OF THE ECONOMIC AND ECOLOGICAL ANALYSIS}

Basing on the assumptions made and the condition of setting the net present value to zero, the breakeven price of electricity was first of all determined. The value of this indicator in the system without capture was 368.5 PLN/MWh (87.7 €/MWh), while for the system with capture it was equal to 377.8 $\mathrm{PLN} / \mathrm{MWh}(90.0 € / \mathrm{MWh})$. This means that for the assumptions made, the system with carbon dioxide capture is less profitable than the system without capture. Break-even price of electricity significantly exceeds the value of the price in conventional coal-fired system with $\mathrm{CO}_{2}$ capture (Kotowicz et al., 2011; Wójcik and Chmielniak, 2010).

According to the current EU emissions trading scheme (ETS), it is important to know the impact of the price for emission allowances on the break-even price of electricity, especially given the fluctuations and growth forecasts of allowances price. The calculations were made in the range of prices from 0 to $80 € /$ tonne of $\mathrm{CO}_{2}$. This analysis did not include the allocation of free emission allowances. In Table 8 break-even price of electricity for the system with and without capture and for two levels of allowance prices, i.e. $6.6 € / \mathrm{tCO}_{2}$ (assumed on the basis of the average price of allowances from the European market in the first half of June 2012) and $40 € / \mathrm{tCO}_{2}$ is presented.

As a reference, values for a case in which the emissions trading scheme does not exist (the price of allowances is equal to zero) is also shown. Fig. 3 shows the change of the value of the break-even price of electricity when changing price of allowances in the range from 0 to $80 € / \mathrm{tCO}_{2}$. 
Table 7. Main input data for the economic analysis

\begin{tabular}{|c|c|c|c|}
\hline Specification & Unit & IGCC & $\mathrm{IGCC}+\mathrm{CCS}$ \\
\hline Gross power of the system & MW & 508.03 & 484.07 \\
\hline Gas turbine power & MW & 289.05 & 305.97 \\
\hline Auxiliary power rate & $\%$ & 13.1 & 24.92 \\
\hline Annual working time & $\mathrm{h} / \mathrm{a}$ & \multicolumn{2}{|c|}{7000} \\
\hline Unit investment costs & $€ / \mathrm{kW}_{\text {installed power }}$ & 1682 & 2024 \\
\hline Construction time & years & \multicolumn{2}{|c|}{3} \\
\hline $\begin{array}{l}\text { Distribution of the investment costs in } \\
\text { subsequent years of construction }\end{array}$ & $\%$ & \multicolumn{2}{|c|}{$15 / 30 / 55$} \\
\hline Share of investor's own means & $\%$ & \multicolumn{2}{|c|}{25} \\
\hline Share of commercial credit & $\%$ & \multicolumn{2}{|c|}{75} \\
\hline Interest of the commercial credit & $\%$ & \multicolumn{2}{|c|}{6} \\
\hline Payback time of the commercial credit & years & \multicolumn{2}{|c|}{10} \\
\hline Exploitation time & years & \multicolumn{2}{|c|}{20} \\
\hline Discount rate & $\%$ & \multicolumn{2}{|c|}{6.2} \\
\hline $\begin{array}{l}\text { The cost of repairs with the division in } \\
\text { consecutive years of operation related to the } \\
\text { investment cost }\end{array}$ & $\begin{array}{c}\% \\
\text { Year } 1 \\
\text { Years } 2 \div 3 \\
\text { Years } 4 \div 7 \\
\text { Years } 8 \div 11 \\
\text { Years } 12 \div 15 \\
\text { Years } 16 \div 20 \\
\end{array}$ & $\begin{array}{l}1.0 \\
1.5 \\
2.0 \\
2.5 \\
3.0 \\
3.5 \\
\end{array}$ & $\begin{array}{c}1.1 \\
1.7 \\
2.2 \\
2.75 \\
3.3 \\
3.85 \\
\end{array}$ \\
\hline Coal price & $€ / \mathrm{GJ}$ & \multicolumn{2}{|c|}{2.38} \\
\hline $\mathrm{CO}_{2}$ emission allowances price & $€ / \mathrm{Mg}$ & \multicolumn{2}{|c|}{40} \\
\hline Employment & pers./MW $\mathrm{MW}_{\mathrm{e}, \mathrm{b}}$ & 2.5 & 2.8 \\
\hline Monthly salary including related costs & $€ /$ post/month & \multicolumn{2}{|c|}{1190} \\
\hline Average depreciation rate & $\%$ & \multicolumn{2}{|c|}{6.67} \\
\hline Income tax rate & $\%$ & \multicolumn{2}{|c|}{19.0} \\
\hline Liquidation value related to the investment & $\%$ & \multicolumn{2}{|c|}{0.2} \\
\hline Rate of exchange & PLN/Euro & \multicolumn{2}{|c|}{4.2} \\
\hline
\end{tabular}

Table 8. Results of the economic analysis

\begin{tabular}{|c|c|c|}
\hline \multirow{2}{*}{$\begin{array}{c}\text { Emission allowances } \\
\text { price, } \\
€ / \mathrm{tCO}_{2}\end{array}$} & \multicolumn{2}{|c|}{$\begin{array}{c}\text { Break-even price of electricity, } \\
\text { PLN/MWh (€/MWh) }\end{array}$} \\
\cline { 2 - 3 } & IGCC & IGCC+CCS \\
\hline 0 & $242.5(57.7)$ & $356.6(84.9)$ \\
\hline 6.6 & $263.3(62.7)$ & $360.2(85.8)$ \\
\hline 40 & $368.5(87.7)$ & $377.8(90.0)$ \\
\hline
\end{tabular}




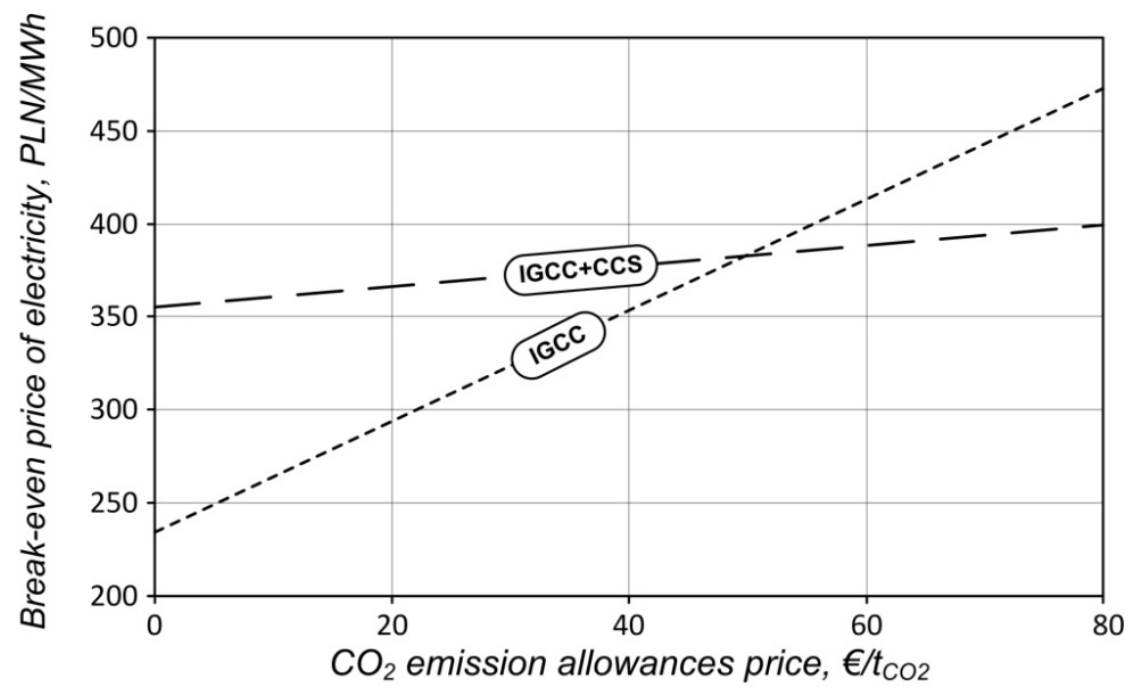

Fig. 3. Break-even price of electricity as a function of a change in the $\mathrm{CO}_{2}$ emission allowances price within the range $\pm 20 \%$

The results of analysis show significance of the emission allowance prices for supporting the system with $\mathrm{CO}_{2}$ capture. In the system with carbon dioxide capture the influence of a change of price of allowances on a change of the cost of generating electricity is much smaller than in the system without capture. Thus, this type of systems is not very sensitive to a change of the price of emission allowances, which is particularly advantageous in the face of growth forecasts of allowance prices. However, at current rates the system integrated with carbon dioxide capture installation is an investment less profitable than the corresponding system without capture.

In the economic analysis of energy systems a proper adoption of unit investment costs is essential. It is not easy in the case of technologies that are still being developed, due to the lack or small number of existing systems that could serve as a reference. Moreover, it can be assumed that with the commercialisation of the developed technology the unit investment cost will relatively decrease. The difference in capital cost between technologies with and without capture will also decrease. Change of the break-even price of electricity in the case of a change of relative investment cost in the range $-0.2 \div 0.2$ is shown in Fig. 4 and Fig. 5. The analysis of the change of the price of coal (as one of the major components of the fixed costs) and annual operation time in the same ranges of variation are also presented.

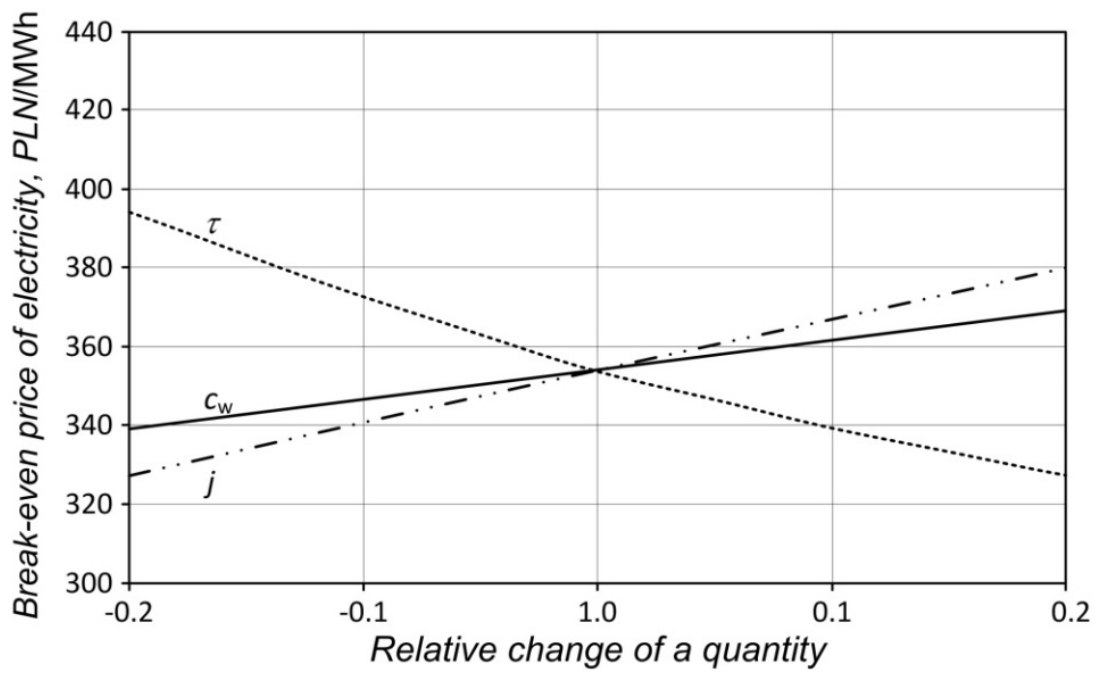

Fig. 4. Break-even price of electricity in IGCC system without $\mathrm{CO}_{2}$ capture as a function of a change of the unit investment cost $(j)$, coal price $\left(c_{\mathrm{w}}\right)$ and annual operation time $(\tau)$ in the range $\pm 20 \%$ 


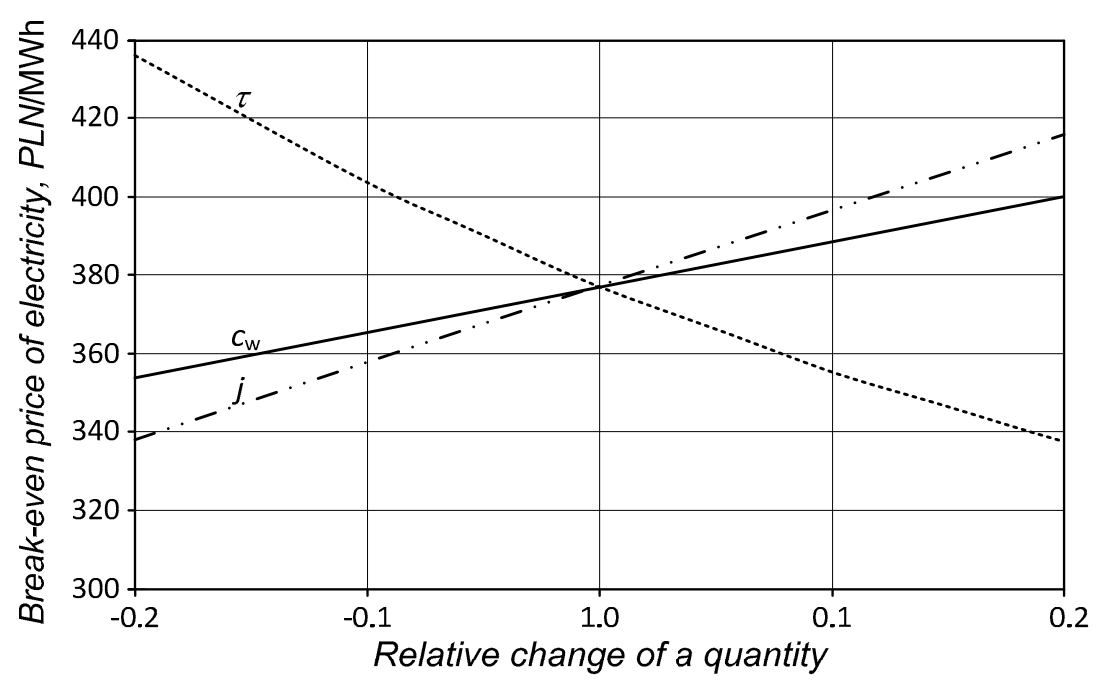

Fig. 5. Break-even price of electricity in IGCC system with membrane $\mathrm{CO}_{2}$ capture as a function of a change in the unit investment cost $(j)$, coal price $\left(c_{\mathrm{w}}\right)$ and annual operation time $(\tau)$ within the range $\pm 20 \%$

The slope of the curve in relation to the x-axis determines the importance of the impact of a certain quantity on the value of break-even price of electricity. Thus, it results from the analysis, that the greatest influence has the annual operation time, then the unit investment cost and the lowest impact has the price of coal. However, in practice, changes of these values can occur in different ranges. While investment in new technologies, which could include coal gasification systems, may decrease with the development of these systems, the coal price is unlikely to significantly decrease in the future. The relatively significant decrease in break-even price of electricity can be achieved by increasing the availability of the IGCC systems. Increasing time from $7000 \mathrm{~h} / \mathrm{a}$ to $8000 \mathrm{~h} / \mathrm{a}$ results in a change by about $20 \mathrm{PLN} / \mathrm{MWh}$ in the case of the system without capture and by about $30 \mathrm{PLN} / \mathrm{MWh}$ in the case of the system with $\mathrm{CO}_{2}$ capture.

An interesting indicator in terms of assessing the integration of energy systems with CCS installations is cost of $\mathrm{CO}_{2}$ avoided emission. Determination of the cost of avoided emissions requires a comparison of the system integrated with the carbon capture installation with a so-called a reference system thus, the unit without integration (in which the $\mathrm{CO}_{2}$ capture is not realized). This indicator shows the cost of carbon dioxide removal, taking into account a decrease of efficiency of the system resulting from the implementation of the $\mathrm{CCS}$ installation. The cost of $\mathrm{CO}_{2}$ avoided emissions is described by the relationship:

$$
C A E=\frac{\left(C_{\mathrm{el}}^{\mathrm{b}-\mathrm{e}}\right)_{\mathrm{REF}+\mathrm{CCS}}-\left(C_{\mathrm{el}}^{\mathrm{b}-\mathrm{e}}\right)_{\mathrm{REF}}}{\left(e_{\mathrm{CO}_{2}}\right)_{\mathrm{REF}}-\left(e_{\mathrm{CO}_{2}}\right)_{\mathrm{REF}+\mathrm{CCS}}}
$$

The cost of avoided emissions (CAE) for IGCC system integrated with $\mathrm{CO}_{2}$ capture was determined in relation to the corresponding system without integration, assuming that market mechanisms in the form of emissions trading scheme do not exist. Determined in such a way cost of avoided emissions gives the information about the limit price of emission allowances at which the two compared solutions have approximately the same economic effectiveness. The most important results of ecological analysis are summarised in Table 8.

Adaptation of the CCS installation in the examined coal-fired systems causes an increase in the auxiliary power and, consequently, decrease of efficiency. Calculated cost of $\mathrm{CO}_{2}$ avoided emission is 193.5 PLN/ $/ \mathrm{CO}_{2}$. It is also the minimum price of $\mathrm{CO}_{2}$ emission allowances for which the break-even price of electricity would be the same in the system with and without carbon dioxide capture. 
Table 9. Cost of avoided emission in the analysed IGCC system

\begin{tabular}{|c|c|c|c|}
\hline \multirow{2}{*}{$\begin{array}{c}\text { Evaluation } \\
\text { index }\end{array}$} & \multirow{2}{*}{ Unit } & \multicolumn{2}{|c|}{ Technology } \\
\cline { 3 - 4 } & & IGCC & IGCC+CCS \\
\hline$e_{\mathrm{CO} 2}$ & $\mathrm{~kg} / \mathrm{MWh}$ & 743.9 & 154.1 \\
\hline$C A E$ & $\mathrm{PLN} / \mathrm{tCO}_{2}\left(€ / \mathrm{tCO}_{2}\right)$ & - & $193.5(46.1)$ \\
\hline
\end{tabular}

\section{CONCLUSIONS}

The main purpose of the analyses presented in this paper was the economic and ecological evaluation of the integrated gasification combined cycle with and without the carbon dioxide capture installation. Carbon dioxide capture is one of the methods that should contribute to the reduction of greenhouse gas emissions to the atmosphere (Chmielniak, 2011). IGCC systems offer many advantages, including in particular the high efficiency of electricity production. When using an external source of heat in order to supply heat for endothermic reactions in gas generator, the efficiency of IGCC systems can even be higher than that of systems currently used (Kawabata et al., 2012). However, investment costs of IGCC system significantly outweigh the costs of conventional systems, so their development is connected mainly with the possibility of implementation of less energy intensive carbon dioxide capture methods than in the case of the methods used for $\mathrm{CO}_{2}$ capture from flue gases after combustion process in conventional systems.

Membrane separation method used in the analyses presented in this paper allows realization of the capture process practically without any energy input, based only on high pressure of the process gas. However, it does not change the fact that it is necessary to implement the shift conversion reactor, to which significant amounts of steam are needed (thereby reducing stream of steam expanded in the turbine), and the carbon dioxide compression installation before its transport to the storage area, which is associated with a significant power needed to drive the compressors. The results of analysis show that the auxiliary power of the system with capture makes the break-even price of electricity, even with the emission allowances prices equal to $40 € / \mathrm{tCO}_{2}$, higher by more than $4.5 € / \mathrm{tCO}_{2}$ than that in the case of the system without capture, and thus, makes this system unprofitable. It should be assumed that in the future, in connection with bringing to operation consecutive commercial or demonstration systems, the profitability of IGCC systems can be increased, especially in the case of an increase in the emission allowances price with simultaneous lowering of the unit investment cost and increasing availability of the systems. To reduce the investment costs associated with the capture process it may be advisable to use membranes selective for $\mathrm{CO}$, which would allow for carbon dioxide capture with omitting the shift reactor. However, further development of the membrane technology is needed.

\section{SYMBOLS}

$\begin{array}{ll}A & \text { amortization } \\ C & \text { cost } \\ C A E & \text { cost of avoided emission } \\ c_{e l} & \text { price of electricity, PLN/MWh (€/MWh) } \\ C F & \text { Cash Flow } \\ e_{C O 2} & \text { unit } \mathrm{CO}_{2} \text { emission } \\ E_{e l} & \text { gross electricity production, } \\ E_{e l} p w & \text { auxiliary power of the system } \\ F & \text { interest on loans }\end{array}$




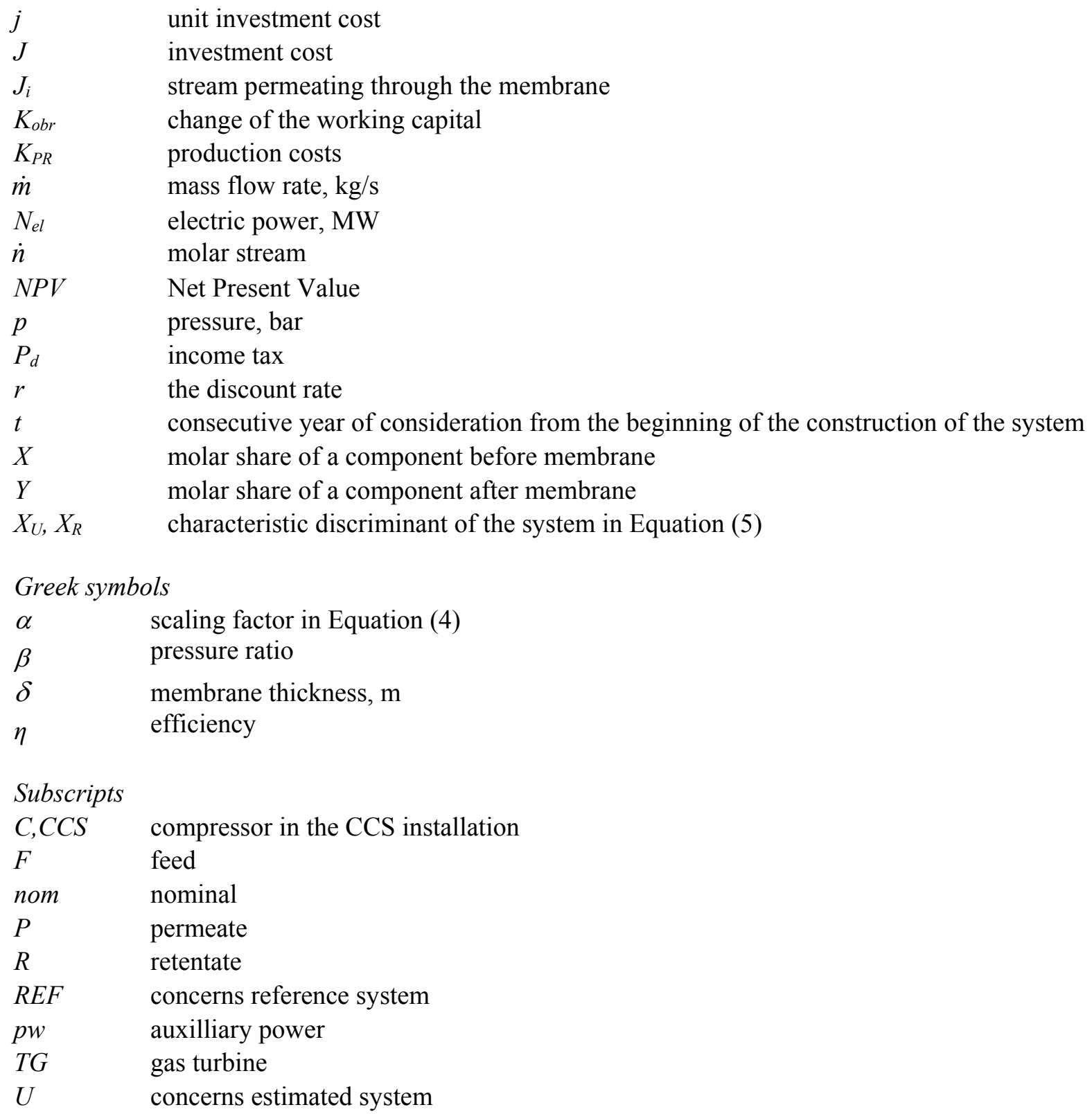

\section{REFERENCES}

Badyda K., Kupecki J., Milewski J., 2010. Modelling of integrated gasification hybrid power systems. Rynek Energii, 88, 47-92.

Bartela Ł., Kotowicz J., 2011. Analiza pracy turbiny gazowej pracującej w układzie IGCC. Rynek Energii, 95, 1622.

Bartela Ł., Skorek-Osikowska A., Kotowicz J., 2014. Economic analysis of a supercritical coal-fired CHP plant integrated with an absorption carbon capture installation. Energy, 64, 513-523. DOI: 10.1016/j.energy.2013.11.048

Bartela Ł., Skorek-Osikowska A., Kotowicz A., 2014. Thermodynamic, ecological and economic aspects of the use of the gas turbine for heat supply to the stripping process in a supercritical CHP plant integrated with a carbon capture installation. Energy Convers. Manage., in press. DOI: 10.1016/j.enconman.2014.02.018.

Chmielniak T., 2011. Rola różnych rodzajów technologii w osiągnięciu celów emisyjnych w perspektywie do 2050. Rynek Energii, 92, 3-9.

Cormos C.C., 2012. Integrated assessment of IGCC power generation technology with carbon capture and storage (CCS). Energy, 42, 434-445. DOI: 10.1016/j.energy.2012.03.025. 
Descamps C., Bouallou C., Kanniche M., 2008. Efficiency of an Integrated Gasification Combined Cycle (IGCC) power plant including $\mathrm{CO}_{2}$ removal. Energy, 33, 874-881. DOI: 10.1016/j.energy.2007.07.013.

Desideri U., Paolucci A., 1999. Performance modelling of a carbon dioxide removal system for power plants. Energy Convers. Manage., 40, 1899-1915. DOI: 10.1016/S0196-8904(99)00074-6.

Feron P.H.M., 2009. The potential for improvement of the energy performance of pulverized coal fired power stations with post-combustion capture of carbon dioxide. Energy Procedia, 1, 1067-1074. DOI: 10.1016/j.egypro.2009.01.141.

General Electric, 2009. $9 F$ syngas turbine. High efficiency syngas-based power generation. Fact Sheet, General Electric, available at: www.ge-energy.com/products_and_services/products/gasification/syngas_turbine.jsp

Grainger D., Hägg M.B., 2008. Techno-economic evaluation of a PVAm $\mathrm{CO}_{2}$-selective membrane in an IGCC power plant with $\mathrm{CO}_{2}$ capture. Fuel, 87, 14-24. DOI: 10.1016/j.fuel.2007.03.042.

Huang Y., Rezvani S., Mcilveen-Wright D., Minchener A., Hewitt N., 2008. Techno-economic study of $\mathrm{CO}_{2}$ capture and storage in coal fired oxygen fed entrained flow IGCC power plants. Fuel Process. Technol., 89, 916925. DOI: 10.1016/j.fuproc.2008.03.002.

Kawabata M., Kurata O., Iki N., Tsutsumi A., Furutani H., 2012. Advanced integrated gasification combined cycle (A-IGCC) by exergy recuperation - Technical challenges for future generations. J. Power Technologies, 92(2), 90-100.

Kotowicz J., 2009. Elektrownie gazowo-parowe. Wydawnictwo Kaprint. Lublin.

Kotowicz J., Bartela Ł., 2012. Optimisation of the connection of membrane CCS installation with a supercritical coal- fired power plant. Energy, 38, 118-127. DOI: 10.1016/j.energy.2011.12.028.

Kotowicz J., Chmielniak T., Janusz-Szymańska K., 2010. The influence of membrane $\mathrm{CO}_{2}$ separation on the efficiency of a coal-fired power plant. Energy, 35, 841-850. DOI: 10.1016/j.energy.2009.08.008.

Kotowicz J., Janusz-Szymańska K., 2010. The influence of $\mathrm{CO}_{2}$ membrane separation on the operating characteristics of a coal-fired power plant. Chem. Process Eng., 31, 681-697.

Kotowicz J., Skorek-Osikowska A., Bartela Ł., 2011. Economic and environmental evaluation of selected.

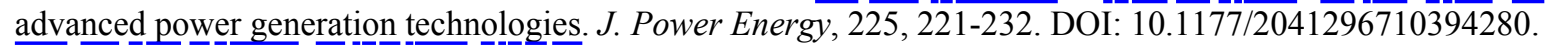

Kotowicz J., Skorek-Osikowska A., Janusz-Szymańska K., 2010. Membrane separation of carbon dioxide in the integrated gasification combined cycle systems. Archives of Thermodynamics, 31, 145-164. DOI: 10.2478/v10173-010-0020-y.

Malko J., 2011. Ekonomika technologii CCS. Rynek Energii, 95, 43-46.

Maurstad O., 2005. An overview of coal based integrated gasification combined cycle (IGCC) technology. Massachusetts Institute of Technology, Publication no. LFEE 2005-002 WP, available at: http://sequestration.mit.edu/pdf/LFEE_2005-002_WP.pdf.

Melchior T., Madlener R., 2012. Economic evaluation of IGCC plants with hot gas cleaning. Appl. Energy, 97, 170-185. DOI: $10.1016 /$ j.apenergy.2012.02.065.

Skorek J., Kalina J., 2005. Gazowe układy kogeneracyjne. Wydawnictwa Naukowo-Techniczne Warszawa.

Skorek-Osikowska A, Kotowicz J, Janusz-Szymańska K., 2012. Comparison of the energy intensity of the selected $\mathrm{CO}_{2}$-capture methods applied in the ultrasupercritical coal power plants. Energy Fuels, 26, 6509-6517. DOI: $10.1021 /$ ef201687d.

Skorek-Osikowska A., Janusz-Szymańska K., Kotowicz J., 2012. Modeling and analysis of selected carbon dioxide capture methods in IGCC systems. Energy, 45, 92-100. DOI:10.1016/j.energy.2012.02.002.

Skorek-Osikowska A. Bartela Ł., Kotowicz J., Job M., 2013. Thermodynamic and economic analysis of the different variants of a coal-fired, $460 \mathrm{MW}$ power plant using oxy-combustion technology. Energy Convers. Manage., 76, 109-120. DOI: 10.1016/j.enconman.2013.07.032

Skorek-Osikowska A, Bartela Ł, Kotowicz J, Sobolewski A, Iluk T. Remiorz L., 2014. The influence of the size of the CHP system integrated with a biomass fuelled gas generator and piston engine on the thermodynamic and economic effectiveness of electricity and heat generation. Energy, 67, 328-340. DOI: 10.1016/j.energy.2014.01.015.

Smitha V.N., Kirkpatrick R.D., Young B.R., 2008. Gasification of New Zealand coals: A comparative simulation study. Energy Fuels, 22, 2687-2692. DOI: 10.1021/ef700704n.

Sun B., Liu Y., Xi Ch., Qulan Z., Ming S., 2011. Dynamic modeling and simulation of Shell gasifier in IGCC. Fuel Process. Technol., 92, 1418-1425. DOI: 10.1016/j.fuproc.2011.02.017.

Ściążko M., Zapart L., Dreszer K., 2006. Analiza efektywności zgazowania węgla połączonego z usuwaniem ditlenku węgla. Polityka energetyczna 9, Zeszyt specjalny. 
Toftegaard M.B., Brix J., Jensen P.A., Glarborg P., Jensen A.D., 2010. Oxy-fuel combustion of solid fuels. Prog. Energy Combust. Sci., 36, 581-625. DOI: 10.1016/j.pecs.2010.02.001

Wójcik K., Chmielniak T., 2010. Wychwyt i transport $\mathrm{CO}_{2}$ ze spalin - efekty energetyczne i analiza ekonomiczna. Rynek Energii, 91, 51-55.

Zhao L., Menzer R., Riensche E., Blum L., Stolten D., 2009. Concepts and investment cost analyses of Multistage membrane systems used in post-combustion processes. Energy Procedia 1, 269-278. DOI: 10.1016/j.egypro.2009.01.038.

Zheng L, Furinsky E., 2005. Comparison of Shell, Texaco, BGL and KRW gasifiers as part of IGCC plant computer simulations. Energy Convers. Manage., 46, 1767-1779. DOI: 10.1016/j.enconman.2004.09.004.

Zheng L., 2011. Oxy-fuel combustion for power generation and carbon dioxide (CO $\mathrm{C}_{2}$ capture. Woodhead Publishing Limited.

Received 23 September 2013

Received in revised form 20 March 2014

Accepted 24 March 2014 